\title{
Multicultural Hybridism as a Dynamic Framework to Reconceptualise Breakout in a Superdiverse and Transnational Context
}

\author{
Xiping Shinnie: Birmingham City University Business School \\ Xiping.Shinnie@mail.bcu.ac.uk \\ Thomas Domboka: Birmingham City University Business School \\ thomas.domboka@bcu.ac.uk \\ Charlotte Carey: Birmingham City University Business School \\ charlotte.carey@bcu.ac.uk
}

Author/s Biography/ies:

Ms Xiping Shinnie is a $\mathrm{PhD}$ researcher from Birmingham City University Business School. Her PhD research focuses on the breakout of Chinese migrant entrepreneurs in Birmingham. Xiping is a Committee Member of the Entrepreneurship in Minority Groups Special Interest Group (SIG), Institute of Small Business and Entrepreneurship (ISBE). Xiping also teaches undergraduate and postgraduate students at the University of Birmingham.

Dr Tom Domboka is an Associate Professor at Birmingham City University where he also teaches entrepreneurship and innovation to postgraduate students as well as supervising several $\mathrm{PhD}$ students. He has particular research interests in ethnic and minority entrepreneurship that broadly encompasses Black, Asian Minority Ethnic (BAME) groups including migrants and refugees. He also has research interests in gender and entrepreneurship. Tom is a member of the Institute of Small Business Entrepreneurship (ISBE), where he currently chairs the entrepreneurship in minority groups conference track and is a founder member of a Special Interest Group (SIG) on entrepreneurship in minority groups that is affiliated to the conference track he chairs. Besides his entrepreneurship research background, Tom comes from a practitioner background, having been an entrepreneur himself and a management consultant. He has been involved with several start-ups and has worked in senior management roles in various organisations in the UK and abroad.

With a creative background, Dr Charlotte Carey has worked as a Researcher and now Senior Lecturer within the Department of Strategy, Applied Management and Marketing at Birmingham City University Business School, focusing on entrepreneurship within the creative industries and entrepreneurship education. Charlotte leads the Entrepreneurship Research Cluster at Birmingham City University Business School. She also co-chairs the Creative Industries track, Institute of Small Business and Entrepreneurship (ISBE). 


\begin{abstract}
:
The conceptual framework of Multicultural Hybridism is adopted to reflect the emerging themes of transnationalism and superdiversity in the context of ethnic minority migrant entrepreneurs breaking out of their ethnic enclaves into mainstream economy. It is constructed as an extension of Mixed Embeddedness theory (Kloosterman, 2006), given that 'Multicultural Hybrid' (Arrighetti, Bolzani, and Lasagni, 2014) firms display stronger resilience with a higher survival rate than enclaved businesses (Kloosterman, Rusinovic, and Yeboah, 2016). With further integration of incremental diversification typology (Lassalle and Scott, 2018), the current study adopts Multicultural Hybridism as a lens to explore the opportunity recognition capabilities of transnational, migrant entrepreneurs who are facilitated by the hybridity of opportunity recognition (Lassalle, 2018) from linking hostcountry and home-country cultures. The hybridity of opportunity recognition focuses on access to markets and resources between transnational ethnic and local multicultural mainstream markets. Through the theoretical lens of Multicultural Hybridism, interviews with 16 Birmingham-based Chinese migrant entrepreneurs have been analysed to shape a dynamic understanding of the multifaceted concept of breakout in a superdiverse and transnational context. The multilayered interpretation of breakout provides an enhanced understanding of the diversity of hybridism between transnational ethnic and local multicultural mainstream markets. This is seen from the perspectives of firm growth and social integration in the current locations and future spaces of transnational migrant entrepreneurs. It goes beyond the narrow imagination of breakout as an economic assimilation process, avoiding the singular conceptualisation of the host-country mainstream market as the only breakout destination for transnational ethnic entrepreneurs.
\end{abstract}

\title{
KEYWORDS:
}

1. Multicultural Hybridism

2. Superdiversity

3. Transnationalism

4. Mixed Embeddedness

5. Breakout 


\section{Introduction}

A new wave of migrant entrepreneurs from dozens of locations across the globe has brought 'superdiversity' (Vertovec, 2007) into the themes of entrepreneurship research. Particular attention has been drawn to the emerging scene of transnational migrant entrepreneurs as a driving force to not only increase employment opportunities but also resolve social tensions in cities across Europe (Baycan-Levent and Nijkamp, 2009). Superdiverse transnational migrant entrepreneurs have demonstrated strong historical continuity, setting up businesses in the same industries as their forerunners, within the mixed embedded mainstream business environment (Ram and Jones, 2008; Jones et al., 2012). In a mixed embedded context, there is an emerging trend of ethnic minority migrant entrepreneurs breaking out of their co-ethnic markets and gaining access to the mainstream economy. From the four-phase breakout strategies identified by Waldinger et al. (1990) to the market and product-oriented diversification typology of ethnic minority entrepreneurs discovered by Lassalle and Scott (2018), the concept of breakout has evolved from an economic assimilation with ethnic migrant businesses gradually losing their ethnic identity (Waldinger et al., 1990) to an incremental diversification growth process to broaden the market base through product and service offerings (Lassalle and Scott, 2015; Lassalle and Scott 2018). By the same token, the concept of 'Multicultural Hybridism' (Arrighetti, Bolzani, and Lasagni, 2014) emerged to reflect the changes of migrant businesses in terms of both their internal structures and external networks with resource providers within the breakout process. It focuses on both individual-level and firm-level determinants of organisational cultural diversity, with evidence of increasing diversity in the employment patterns of migrant businesses.

Meanwhile Birmingham, as the second largest metropole in the UK, is a 'global' (Sassen, 1988) city with a significant and diverse ethnic economy (McEwan, Pollard, and Henry, 2005), which entails rich experiences of culture, migration and entrepreneurship (Henry, McEwan, and Pollard, 2002). It is arguably an ideal locality to conduct a structured investigation into the characteristics of ethnic culture within the emerging breakout journeys of ethnic minority migrant businesses. In line with the national statistics in England, between 2001 and 2011, Birmingham has shown a sharp increase in the number of Chinese migrants arriving in the city, which almost doubled from 5,106 in 2001 to 12,712 in 2011 (ONS, 2001; 2011). The Chinese population is one of the fastest-growing populations in Birmingham (ONS, 2001; 2011). It is further estimated that by 2021, the Chinese population will experience a further increase to 13,450 (Simpson, 2007). Previous studies have shown that although migrant entrepreneurs from Chinese communities are considered to be particularly entrepreneurial, in the UK Chinese migrant entrepreneurs are under-researched (Barrett, Jones, and McEvoy, 1996; Chan, 1997; Ram and Jones, 2008; Wu and Liu, 2014). This chapter focuses on the lived experiences of Chinese migrant entrepreneurs in Birmingham from a multicultural hybridism perspective, to reconceptualise the dynamic concept of breakout.

On the basis of both individual and firm-level cultural diversity of Multicultural Hybridism (Arrighetti et al., 2014) as well as Mixed Embeddedness theory (Kloosterman, 2006) with integration of incremental diversification typology (Lassalle and Scott, 2018), at the individual level of the entrepreneur, this chapter provides discussions on the construction of Multicultural Hybridism as a dynamic theoretical framework, used to examine entrepreneurial opportunity recognition capabilities with respect to access to markets and resources between transnational ethnic and local multicultural mainstream markets. The conceptual framework is grounded in the lived experiences of 16 Birmingham-based Chinese migrant entrepreneurs, with findings of transnational Chinese entrepreneurs not only breaking into host-country British mainstream markets, but also growing businesses in the home-country Chinese mainstream economies. The chapter is therefore structured as follows: Section 1 introduces the research background. Section 2 discusses the construction of a conceptual framework of Multicultural Hybridism. Section 3 presents the research design and 
Multicultural Hybridism as a Dynamic Framework

to Reconceptualise Breakout in a Superdiverse and Transnational Context

Section 4 provides data analysis drawn from interviews, whilst finally Section 5 draws conclusions from the findings.

\section{Multicultural Hybridism as a Dynamic Conceptual Framework for Breakout 2.1 A Dynamic Concept of Multicultural Hybridism}

Inspired by the seminal research on ethnic enclave economies (Wilson and Portes, 1980), the concept of breakout is constructed on the basis that ethnic minority migrant businesses are developed through divergent trajectories, notably of ethnic change rather than a unified assimilation process to exit from the ethnic enclave and enter into the mainstream market (Aldrich and Waldinger, 1990; Waldinger, 1993). In Britain, breakout as a diversification process has been categorised into horizontal breakout and vertical breakout (Ward, 1985; Ward, 1986). Further studies have focussed on the feasibilities, barriers, strategies and implications of breakout as well as trajectories of new migrant enterprises from a Mixed Embeddedness perspective (Ram and Hillin 1994; Ram et al., 2003; Jones et al., 2014). Within the Mixed Embeddedness framework, breakout is mainly understood as a transformation process of migrant entrepreneurs, moving from low-profit stagnant vacancy-chain openings, with ground-level requirements for skills and a low threshold of human capital, to a high growth postindustrial market, which requires a high threshold of human capital (Kloosterman, 2010; Kloosterman, Rusinovic, and Yeboah 2016).

In recent years, a growing number of researchers have engaged in discussions on superdiversity and transnationalism in examination of breakout process (Ram et al., 2013; Kloosterman et al., 2016; Vershinina and Rodgers, 2019). Noticeably, there is a trend to integrate superdiversity and transnationalism into Mixed Embeddedness theory with a focus on reconceptualisation of opportunity structure (Kloosterman, 2006; Kloosterman et al., 2016; Lassalle and McElwee, 2016). In particular, opportunity structure has been studied through opportunity recognition as a decisionmaking process (Lassalle and McElwee, 2016; Lassalle, 2018). Further, Barrett and Vershinna (2017) studied diversity within and between ethnic groups in a transnational context due to divergent transformation of ethnicities in space and time. Meanwhile, an increasing number of studies have foregrounded a cultural perspective with an attempt to understand the dynamism of breakout in superdiverse and transnational contexts (Arrighetti et al., 2014; Allen and Busse, 2016; Gonzalez and Campbell, 2018; Wang and Warn, 2019). Particularly, Multicultural Hybridism as a form of organisational cultural diversity has been examined both from a breakout resource to solution perspective (Arrighetti et al., 2014) and through a typology of breakout strategies (Gonzalez and Campbell, 2018).

To make sense of the emerging themes of breakout, a conceptual framework of Multicultural Hybridism is proposed as an extension of Mixed Embeddedness theory (Kloosterman, 2006), given that 'Multicultural Hybrid' (Arrighetti et al, 2014) firms display stronger resilience, with a higher survival rate, than enclaved businesses (Kloosterman et al, 2016). Through interviews with 130 migrant entrepreneurs in Italy, Arrighetti et al. (2014) concluded that Multicultural Hybrid firms are increasingly entering mainstream markets, changing both internal firm structures and external networks in our multicultural societies. The conceptual framework of Multicultural Hybridism adopted in this study is constructed on the basis of Mixed Embeddedness theory (Kloosterman, 2006) with the integration of both Multicultural Hybridism as organisational cultural diversity (Arrighetti et al., 2014) and the incremental diversification typology (Lassalle and Scott, 2015; Lassalle and Scott, 2018). Therefore, in this study Multicultural Hybridism refers to entrepreneurial opportunity recognition towards access to markets and resources. This is facilitated by duality and hybridity in the opportunity cognition of migrant entrepreneurs between their host-country and home-country cultures during their breakout journeys. The concept of Multicultural Hybridism is developed to construe a dynamic understanding of the multifaceted concept of breakout in a superdiverse and 
Multicultural Hybridism as a Dynamic Framework

to Reconceptualise Breakout in a Superdiverse and Transnational Context

transnational context. It goes beyond the narrow imagination of breakout as an economic assimilation process, avoiding the singular conceptualisation of the host-country mainstream market as the only breakout destination for transnational ethnic entrepreneurs.

\subsection{A Typology of Transnational Migrant Entrepreneurs}

The conceptual framework of Multicultural Hybridism consists of two facets. The first facet contains a typology of transnational migrant entrepreneurs as shown in Figure 1. The design of the first facet includes the typology of markets, according to accessibility and growth potential (Kloosterman, 2006), alongside the typology of ethnic minority entrepreneurs from a market and product perspective (Lassalle and Scott, 2018). The integrational of the typology of markets and the ethnic minority entrepreneur is viewed through the lens of transnationalism (Vertovec, 1999; Waldinger and Fitzgerald, 2004; Vertovec, 2009; Wahlbeck, 2018).

\section{FIGURE 1}

\section{Figure 1. Opportunity Structure: A Typology of Transnational Migrant Entrepreneurs adapted from Kloosterman (2006) and Lassalle and Scott (2015)}

Transnationalism is considered as multistranded social ties and interactions linking people and institutions across the borders of nation-states (Basch, Schiller, and Blanc, 1994). It is both a hybrid blending process of cultural reproduction and an avenue of capital in the global economy, with migrant entrepreneurs producing significant impacts on both their societies of origin and settlement as well as beyond (Vertovec, 1999). A transnational approach of Mixed Embeddedness enables an understanding of transnational entrepreneurship as a dynamic and multifocal agent (Solano, 2016; Bagwell, 2018). This approach offers analysis of the levels of transnationalism together with local, regional and national levels of embeddedness rather than a separate study of transnationalism in isolation (Wahlbeck, 2018). Meanwhile, according to the typology of ethnic minority entrepreneurs from a market and product perspective (Lassalle and Scott, 2015; Lassalle and Scott, 2018), there are four types of entrepreneur, namely Enclave-Market Entrepreneurs, Niche-Market Entrepreneurs, Middleman Entrepreneurs and Mainstream Market Entrepreneurs. Given the significance of transnationalism in breakout, the typology of transnational migrant entrepreneurs includes three additional types of entrepreneur: Transnational Enclaved Entrepreneurs, Transnational Middleman Entrepreneurs and Transnational Mainstream Entrepreneurs. Designed on the basis of the typology of markets according to accessibility and growth in Mixed Embeddedness theory (Kloosterman, 2006), there are three dimensions in the typology of transnational migrant entrepreneurs, namely 
Growth Potential, Transnational Capital and Spatial Clustering. The three dimensions are designed with an intention to analyse Opportunity Structure in a transnational context.

The first dimension is Growth Potential, which relates the resources of the migrant entrepreneur to opportunity structures. According to Kloosterman (2006), 'Vacancy-chain openings' requires a lower threshold of human capital with low growth potential, whereas Post-industrial markets involve a high threshold of human capital with high growth potential. The same principle applies to the five types of entrepreneur in the typology of transnational migrant entrepreneurs. Among the five types of entrepreneur, Enclaved Entrepreneurs possess the lowest growth potential while Transnational Mainstream Entrepreneurs hold the highest growth potential. Transnational Capital as the second dimension is incorporated to reflect the significance of transnational resources in a breakout context. Given that in an overarching, interactionist, transnational social network, entrepreneurial strategic resources include financial capital, labour capital and social capital (Kloosterman and Rath, 2018), transnational capital is analysed in the forms of transnational financial capital, transnational labour capital and transnational social capital. Spatial Clustering is the third dimension, and has played a significant role in the development of migrant entrepreneurship in general (Wilson and Portes, 1980; Webner, 1990; Waldinger, 1993; Zhang et al., 2016) and Mixed Embeddedness theory in particular (Kloosterman et al., 1999). Spatial Clustering is of particular significance in a transnational context, as a substantial number of migrant entrepreneurs have become transnational with the capacity to maintain transnational space over long periods of time, even through generations (Valenzuela-Garcia et al., 2018). The construction of Spatial Clustering focuses on the dynamism between the geographical location as the meeting point of local as well as transnational spatial element, with industrial clustering representing the local industrial space and ethnic clustering showing access to the transnational ethnic market.

\subsection{A Framework for the Breakout Process in Superdiverse Contexts}

The second facet of Multicultural Hybridism includes a Framework for the Breakout Process in Superdiverse Contexts, as shown in Figure 2. The framework is constructed on the basis of the diversification process (Lassalle and Scott, 2018) and Multicultural Hybridism (Arrighetti et al., 2014), incorporating the concept of superdiversity (Vertovec, 2007; Sepulveda, Syrett, and Lyon, 2011; Zubair and Brzozowski, 2018; Yamamura and Lassalle, 2020).

FIGURE 2

Figure 2. Opportunity Recognition:

A Framework for the Breakout Process in Superdiverse Contexts adapted from Lassalle and Scott (2015) and Arrighetti, Bolzani, and Lasagni (2014) 
Superdiversity signifies a new era of migration and multicultural diversity in Britain, with an unprecedented level of complexity in terms of demographic diversity and social patterns (Vertovec, 2007). It draws attention to internal differences of ethnic entrepreneurial resources within ethnic groups, in which the dynamism between the superdiversity of migration and changes in opportunity structure brings new meaning to the mix of Mixed Embeddedness theory (Barberis and Solano, 2018; Yamamura and Lassalle, 2020). This means migrant entrepreneurs create business opportunities through recognitions of the contextualised opportunity structure (Yamamura and Lassalle, 2020). The interplay between opportunity structure and opportunity recognition reveals the decisionmaking process of the entrepreneur (Lassalle, 2018). Meanwhile, according to Arrighetti et al. (2014), the determinants of Multicultural Hybridism as an organisational resource to solve cultural diversity include the size of the founding team, the business's maturity, the entrepreneurs' hostcountry language competence and the entrepreneur's individual goal. Gender, class, education and migration history are closely linked to opportunity cognition (Arenius and Clercq, 2005; FarrWharton and Brunetto, 2007; Ma, Huang, and Shenkar, 2011; Lassalle, 2018), which also strongly impact on the entrepreneurs' host-country language competence and the goals of entrepreneurs to break out of the ethnic niche market (Beiser and Hou, 2000; Zhang, 2012; Arrighetti et al., 2014; Jones et al., 2014). Therefore, the current study incorporates gender, class, education and migration history as factors shaping the breakout process in superdiverse contexts. The interrelationship of Opportunity Recognition and Opportunity Structure serves as the basis to reconceptualise breakout as a superdiverse multicultural hybrid transformation process of ethnic minority migrant entrepreneurs breaking out of transnational ethnic markets into multicultural mainstream markets. The Framework for the Breakout Process in Superdiverse Contexts includes multidimensional breakout paths to show the current locations as well as the intended future entrepreneurial spaces of migrant entrepreneurs. In particular, with the introduction of the home-country mainstream market parallel to the host-country mainstream market, it is intended to avoid the singular conceptualisation of the host-country mainstream market as the only breakout destination for ethnic entrepreneurs.

\section{Research Methodology}

\subsection{Research Context}

Given that entrepreneurship is a contextualised event and entrepreneurship research takes place in a specific context (Welter, 2011), it is essential to study the research context, with a focus on the development of the migration history and entrepreneurial transformation of the Chinese community within the city context of Birmingham. Since Birmingham is not a coastal city, large-scale Chinese migrations to Birmingham have been relatively recent, with the majority of Birmingham's Chinese population arriving as a result of post-war migration (Parker, 1995). There has been a continued growth of migrants from Mainland China in the form of students, skilled workers and investor entrepreneurs. The Chinese Quarter has served as a central meeting point for the city's Chinese community, with long-established Chinese supermarkets and restaurants as well as a growing number of Chinese community organisations and professional service firms, including overseas Chinese capital investment offering the expansion of transnational links for Birmingham (McEwan et al., 2005). Chinese migrant communities in Birmingham manifest the complexity of superdiversity, which not only encompasses the social economic factors motivating Chinese migrants to settle in Birmingham but also entails the dynamisms between the historical spatial development of Birmingham's Chinese Quarter and the evolution of the diaspora culture of the Chinese community in Birmingham (Henry et al., 2002). However, research into Chinese migrant entrepreneurs is scarce (Chan, 1997; Ram and Jones, 2008; Wu and Liu, 2014). Therefore, the breakouts of Chinese entrepreneurs are deeply embedded within the superdiverse and transnational city context of Birmingham, but without representative scholarship.

\subsection{Research Design}


Given the interpretivist qualitative nature of this current research, grounded theory was adopted to investigate the breakout experiences of Chinese migrant entrepreneurs in Birmingham (Starks and Trinidad, 2007), since theories are directly grounded from the data, offering greater confidence to researchers (Urquhart and Fernández, 2006). The aim of the research was to identify trends from a number of leading entrepreneurs within the Chinese migrant business community in Birmingham: a group size of 16 was arrived at through a process of thematic saturation (Mason, 2010). Two criteria were used to select participants: Firstly, the group was limited to first-generation Mainland Chinese entrepreneurs, which means Chinese entrepreneurs from Hong Kong are not included in the sampling due to differences in their social, cultural and migration background. Secondly, the selected participants are entrepreneurs with majority ownership of UK micro-businesses and SME businesses. It is noted that this current study adopts the EU standard, EU recommendation 2003/361, ${ }^{1}$ to measure micro-businesses and SMEs. According to Table 1 (Please see Appendix I), most of the entrepreneurs originally came to the UK as international students, with high educational qualifications obtained in the UK. For the three participants who migrated as skilled workers, their spouses were also highly educated migrants who had completed their Bachelor's or Master's degrees in the UK or in their home countries. All the interviewees were highly skilled migrant entrepreneurs, possessing high levels of academic and/or professional skills.

Semi-structured interviews were used in this research, according to a partially developed script, encouraging the entrepreneurs to elaborate their stories. One of the key questions asked was on their definitions of breakout. The entrepreneurs would start with their own stories of setting up and maintaining their businesses in Birmingham. Then they were asked whether or to what extent their business has broken into British mainstream markets. Based on the answers, they were asked about their constructive experiences of breaking into British mainstream markets in terms of financial, social and labour capital, with their access to British mainstream markets reflected in their strategies on the locations of their businesses. Finally, at the end of the interviews, the entrepreneurs were asked about their understandings or definitions of breakout. All 16 interviews were conducted in Mandarin Chinese translated and transcribed by the researcher. QSR-NVivo was used in the data analysis, given that it facilitates many aspects of the grounded theory process, from design and sampling through to data analysis, theoretical development and presentation of findings (Hutchison et al., 2009).

\section{Research Findings}

\subsection{Opportunity Structure of Breakout: Hybridity in Transnationalism}

Analysis of all 16 entrepreneurs was conducted on the basis of their forms of transnational capital, the characteristics of spatial clustering as well as the growth potential of their businesses. As such all were examined according to the first facet of Multicultural Hybridism framework, shown as follows in Figure 3.

\section{FIGURE 3}

\section{Figure 3. Transnational Opportunity Structure on the Basis of a Typology of Transnational Migrant Entrepreneurs}

\footnotetext{
${ }^{1}$ According to EU recommendation 2003/361, the main determining factors of micro and SME businesses include two of the following three criteria, namely staff headcount, balance sheet total and turnover.
} 
A distinct attribute of the breakout structure is that most entrepreneurs are located between the typologies of 'Transnational Middleman Entrepreneur' and 'Transnational Mainstream Entrepreneur' as well as between those of 'Transnational Mainstream Entrepreneur' and 'Transnational Enclaved Entrepreneur'. This reveals the hybrid nature of the transnational opportunity structure in this breakout context, and highlights that migrant entrepreneurs are constantly comparing transnational and local entrepreneurial resources. The hybridity in the transnational opportunity structure of breakout contains three meanings.

First, in terms of capital, all 16 Chinese entrepreneurs interviewed decided to resort to a combination of transnational and local capital. From the perspective of financial capital, 10 out of the 16 entrepreneurs started their businesses with their own savings through earnings from previous employment in either the UK or China. They also had access to capital from local financial institutions, friends and family. Two entrepreneurs raised capital from their home country in addition to their own savings. Another two set up their businesses entirely on their own savings. With respect to labour capital, all the 16 entrepreneurs employed a combination of Chinese and British workers. Entrepreneurs in the catering industry mostly employed workers from within the Chinese community, with the intention to recruit more staff from outside the Chinese community to fill the skill gap of a chef shortage. In the service, creative and advanced manufacturing industries, the entrepreneurs employed more than $50 \%$ of their employees from outside the Chinese community. They valued the diversity of the workforce and saw this as a competitive advantage for their business. As to social capital, all 16 entrepreneurs engaged in social connections from both transnational Chinese ethnic and local multicultural mainstream markets. Two entrepreneurs from the catering industry started their businesses on the basis of social capital within the Chinese niche market with increased shares in the mainstream British markets. Of the eight entrepreneurs in service industries, three entrepreneurs started their businesses in both the mainstream and Chinese niche markets in the UK, with social connections in both the British mainstream and Chinese niche markets; three entrepreneurs started their businesses in the Chinese niche market both in the UK and in China with social connections in both markets; two entrepreneurs utilised their social connections in both the mainstream markets in the UK and in China to help mainstream British businesses to enter the mainstream Chinese market.

Second, with respect to spatial clustering, all 16 entrepreneurs demonstrated a significant degree of hybridity. They decided to locate their businesses in a geographical location within their industrial clustering, which was within or at least close to the Birmingham Chinese Quarter. The two entrepreneurs in the catering industry decided to locate their businesses within the Birmingham Chinese Quarter, given that this location facilitated the needs of both local industrial clustering and transnational ethnic clustering. Five of the entrepreneurs in the service industry chose to locate their businesses half-way between their industrial clusters and the Birmingham Chinese Quarter. Three of the entrepreneurs in the service industry located their businesses in the Birmingham Chinese Quarter regardless of their industry clusters. All three entrepreneurs in the creative industry established their businesses in locations which were between their industry clusters and the Birmingham Chinese Quarter. In contrast, all three entrepreneurs in the advanced manufacturing industry set up their businesses in locations within their industry clusters, within travelling distance to the Birmingham Chinese Quarter. The different strategies taken by all the 16 entrepreneurs from the four sectors analysed illustrates the divergent barriers of access to various markets. For entrepreneurs in an industry that maintained a strong presence of Chinese businesses like the catering industry, the markets in these industries were wide open to Chinese entrepreneurs without any barriers. Entrepreneurs in these markets decided to locate their businesses in the Birmingham Chinese Quarter or surrounding areas, since their industry clusters and ethnic clusters were in line with each other. However, growth potential within these open markets was relatively low. In markets 
with greater growth potential including the service industry and creative industry, the entrepreneurs ran into situations where their industry clusters and ethnic clusters were divergent. To balance the interests of all sides, over half of the entrepreneurs decided to locate their businesses half-way between their industry clusters and the Birmingham Chinese Quarter. A small number of entrepreneurs located their businesses in the Birmingham Chinese Quarter, keeping a distance from their industry clusters. Decisions on the locations of the businesses illustrated not only the raising of barriers of access to these relatively high growth markets but also the huge benefits of staying within or close to the ethnic clusters, given that all the entrepreneurs set up their businesses within or near the Birmingham Chinese Quarter. In contrast, all three entrepreneurs in the advanced manufacturing industries established their businesses within their industry clusters. This indicated that in a high growth sector like the advanced manufacturing industry, there were high barriers of access to the markets for Chinese ethnic entrepreneurs. When the positive impact of Chinese ethnic clusters became minimal, the Chinese ethnic entrepreneurs decided to stay within their industry clusters in order to maintain access to markets and grow their businesses.

Third, hybridity in transnationalism is observable, as the interrelation between transnational capitals and spatial clustering reveals the plurality of opportunity structure in this breakout context. Social and structural embeddedness are mixed through a complex nesting of local, regional, national and transnational entrepreneurial resources, with entrepreneurs continuously making decisions on the degree and form of hybridity which is structurally permitted to achieve the maximum financial gain. In particular, five entrepreneurs were considered as 'Transnational Enclaved Entrepreneurs', (two from the catering industry and three from the service industry). Due to its historical success and strong performance within the catering industry (McEvoy and Hafeez, 2007), the Chinese catering industry functioned as an enclaved market providing ethnic clustering for catering businesses as well as enterprises within service markets. In addition, four entrepreneurs were regarded as 'Transnational Middleman Entrepreneurs', two from the service industry and two from the creative industry. Chinese entrepreneurs in the service and creative industries applied their transnational social capital to both the British and Chinese mainstream markets. They topped this up with their industrial expertise as well as financial and labour capital in the UK and China to establish and grow their businesses. Finally, seven entrepreneurs were viewed as 'Transnational Mainstream Entrepreneurs', three from advanced manufacturing industry, three from service industries and one from a creative industry. This category of Chinese entrepreneurs set up their businesses in local Chinese niche markets or in transnational Chinese ethnic markets with subsequent strong growth in the mainstream British market.

\subsection{Opportunity Recognition towards Breakout: Superdiverse Multicultural Experience}

Given the hybridity in transnationalism as analysed in Section 4.1, the typology of transnational migrant entrepreneurs illustrates the current locations of the 16 Chinese migrant entrepreneurs. In order to further understand their future spaces, the notion of opportunity recognition was incorporated to examine their intended future breakout destinations. As discussed in Section 2.3, the focus is on factors shaping breakout process functions as key points to deconstruct the cognition process of opportunity structures, which are adapted from the determinants of Multicultural Hybrid organisational cultural diversity (Arrighetti et al., 2014) and the process of opportunity recognition (Lassalle, 2018). These factors include gender, class, education and migration. All 16 entrepreneurs were analysed according to the second facet of the Multicultural Hybridism framework, shown as follows in Figure 4. 


\section{FIGURE 4}

\section{Figure 4. Superdiversity of Opportunity Recognition on the Basis of A Framework for the Breakout Process in Superdiverse Contexts}

A significant feature of opportunity recognition within the breakout structure is that breakout is multidimensional, meaning that different groups of migrant entrepreneurs break into different market spaces: First, 'Transnational Middleman Entrepreneurs' are the most active group, with entrepreneurs from creative and service industries. All four entrepreneurs in this group decided to increase their market shares or supplier base in the UK mainstream market, with three aspiring to explore the Chinese mainstream market following their steady growth in mainstream UK markets. Second, 'Transnational Mainstream Entrepreneurs' are divided into two categories, 'Home-country' and 'Host-country Transnational Mainstream Entrepreneurs', with entrepreneurs in this group mainly from the advanced manufacturing, creative and service industries. One 'Home-country Transnational Mainstream Entrepreneur' from the advanced manufacturing industry expanded his China-based manufacturing business into the UK mainstream market, in order to internationalise his business. In the meantime, two 'Host-country Transnational Mainstream Entrepreneurs' had developed business links to grow their UK-based businesses in the Chinese mainstream market due to their lack of confidence in the growth potential of the UK mainstream market. Similarly, due to concern about the limited development space and low profit margins in the UK mainstream market, two 'Host-country Transnational Mainstream Entrepreneurs' planned to shift their businesses to transnational enclaved markets to ensure a more sustainable future. Third, 'Transnational Enclaved Entrepreneurs' were the group with the lowest intention to move into other market spaces. Entrepreneurs in this group were from the catering and service sectors. Although through diversification of products and assets, they were equipped to enter the local mainstream British markets, they were not motivated to break into the mainstream market, since the Chinese ethnic market provided the economic, cultural and social benefits they needed for their businesses. The future breakout intentions of these 16 Chinese entrepreneurs illustrate the trend of breakout the process in superdiverse contexts, with transnational Chinese entrepreneurs not only breaking into British mainstream markets but also breaking beyond British mainstream markets into Chinese mainstream markets and breaking back into Chinese niche markets.

\subsection{The Multicultural Hybrid Construction of Breakout}

Hybridity in transnationalism reveals the plurality of opportunity structure, which places migrant entrepreneurs in a situation of continually updating their understanding of the available local and transnational entrepreneurial resources. Determinants of the breakout process bring superdiversity into multicultural hybrid breakout experiences. Through the lens of Multicultural Hybridism, this 
study is intended to reconceptualise breakout in a superdiverse and transnational context. Eight entrepreneurs stated that for entrepreneurs to successfully break into mainstream markets, breakout should happen at both the personal and professional levels. At the personal level, there were three interpretations of breakout. Five entrepreneurs considered breakout at a personal level insomuch as it provided social confidence through connecting with the local British culture and social life, leading to a desire to take an active role in local social and political events. For instance, X stated:

I would attempt a three-dimensional definition of breakout from the perspective of the entrepreneur. ... Thirdly, the entrepreneur is able to confidently mix with the local culture and social life, drawing inspirations from daily life to his/her businesses through hybrid fusion with the multicultural local community.

Meanwhile, three entrepreneurs believed that at the personal level, Chinese entrepreneurs successfully breaking into mainstream British markets possess cultural capabilities to mix the homecountry Chinese culture with the host-country British culture with a deep appreciation of the multiculturalism in current British society. $\mathrm{J}$ discussed:

Breakout refers to mixing with the local mainstream market. I am a Chinese migrant entrepreneur in Birmingham. This requires me to adapt myself into a multicultural mix, with my deep roots in Chinese culture fused with my strong aspirations towards British culture as well as my genuine appreciation and dynamic interactions with other minority cultures in Birmingham.

Furthermore, the fusion between British and Chinese cultures was experienced as a blending of Chinese Confucianism with British multiculturalism. According to the participants, central to Confucianism was the thought of '仁 Ren (Humanity)', ${ }^{2}$ which was constructively mixed with British multicultural business values. $C$ expressed:

Chinese entrepreneurs successfully breaking into British markets must have the capabilities to blend the two cultures in a deep sense. For me and many Chinese entrepreneurs, Confucianism has a profound influence on our behaviours as entrepreneurs as well as the ways we run our businesses. I truly believe this quote from Confucianism: 'What you do not wish for yourself, do not impose on others (己所不欲, 勿 施于人)'. It shows deep appreciation of humanity, which is also recognised by both the English and many minority business communities in the UK. In particular, with similar cultures, Indian business communities have many shared values with Confucianism.

At a professional level, entrepreneurs shared their understandings of breakout from three perspectives. They expressed their understanding of breakout in respect to professionalism in the British mainstream market, meaning that Chinese entrepreneurs successfully breaking into British mainstream markets should learn to conduct business activities according to the professional standings of British mainstream markets, as X stated:

I would attempt a three-dimensional definition of breakout from the perspective of the entrepreneur. Firstly, the entrepreneur needs to obtain membership of the relevant industry and local business

\footnotetext{
${ }^{2}$ There are a number of wide accepted translations of '仁', including 'benevolence', 'perfect virtue', 'goodness' and 'human-heartedness'.
} 
association such as Birmingham Chamber of Commerce. Consequently, he/she builds wide business connections within the industry and the local business community. Secondly, the entrepreneur becomes a main player of the association so that he/she has opportunities to standardise the regulation and influence the future development of the industry.

At the same time, from the perspective of integrating professionalism from British mainstream markets into Chinese business values, a number of participants shared their thoughts on taking family values as an integration point to fuse professionalism at the heart of Chinese business culture. D explained:

Breakout means Chinese entrepreneurs are able to comprehend the spirit of professionalism in Chinese ways. Professionalism means, firstly, entrepreneurs shall conduct their businesses through the rule of law, and, secondly, there are not only financial responsibilities to generate profit but also social responsibilities to positively impact society. Therefore, professionalism is similar to the family values in Chinese business culture. This means all the members of the family shall obey the same rules, and all the family members shall bear both the social and economic responsibilities of the family. Beyond the rules and responsibilities, businesses in the same community are like members of the same family, providing warm support to each other and to the whole of society.

Moreover, breakout was described as an expression of cultural confidence, showing deep appreciation of both the British and Chinese cultures in professional business environment. This cultural confidence motivated participants to create businesses and develop their brands with a fusion and re-creation of both British and Chinese cultures. Y shared his thoughts on cultural confidence:

Breakout requires entrepreneurs to develop a great sense of cultural confidence. By cultural confidence I mean a Chinese entrepreneur shall feel confident to develop himself/herself as a Chinese entrepreneur through positive interactions with British as well as European, Indian, Pakistani and Black entrepreneurs as well as entrepreneurs from other ethnic origins. It also means the Chinese entrepreneur shall feel confident to develop his/her Britishness with entrepreneurs in China. Cultural confidence is developed through the re-creation of both British and Chinese cultures with multilayered development through time to create real value for businesses and brands.

Therefore, grounded in the lived experience of these sixteen entrepreneurs, breakout is interpreted as the entrepreneurial process of hybrid fusion to mix local economic, social and cultural embeddedness with transnational embeddedness. Doing this transforms the entrepreneur into a multicultural mix, confidently fusing their home-country culture with the host-country mainstream culture as well as other ethnic minority cultures, and vice versa. The aim of breakout is not only to achieve greater growth potential but also to become a major player in the local sphere to influence industrial development as well as the local social and culture spaces in both the host and home countries and beyond. 


\section{Discussion and Conclusion}

To reflect the emerging themes of transnationalism and superdiversity in migrant entrepreneurship, a conceptual framework of Multicultural Hybridism is proposed to extend Mixed Embeddedness theory into a transnational breakout context. The construct of Multicultural Hybridism, from the perspective of the entrepreneur, is intended to shed light on the multifaceted concept of breakout. It goes beyond the narrow imagination of the host-country mainstream market as the only breakout destination for ethnic entrepreneurs. The conceptual framework of Multicultural Hybridism consists of two facets, namely a Typology of Transnational Migrant Entrepreneurs and a Framework for the Breakout Process in Superdiverse Contexts. Analysis of our interviews reveals the hybrid nature of the transnational opportunity structure in this breakout context. The hybridity in transnational opportunity structure of breakout has three forms:

- Hybridity between transnational and local entrepreneurial resources, which is linked to the breakout destination of entrepreneurs.

- Hybridity between transnational and local spatial clustering, which indicates the levels of barriers of access to various markets.

- Hybridity in the interaction between transnational capital and spatial clustering as a mixed nesting of local, regional, national and transnational embeddedness.

The notion of opportunity recognition is incorporated to enhance understandings of the decisionmaking process of the transnational opportunity structure of breakout, with a focus on factors shaping the breakout process. Analyses of the 16 interviews show that breakout experiences of entrepreneurs are multidimensional, meaning that different groups of migrant entrepreneurs tend to break into different market spaces. Firstly, in terms of gender, female entrepreneurs are mainly in the service and creative industries, with intentions to enter into stable ethnic niche market spaces focusing on not only financial gain but also the social impact of their businesses. This is in line with previous studies which point out that Chinese ethnic entrepreneurs are less associated with higher growth sectors (Daniel, Henley, and Anwar, 2019). Secondly, in terms of migration history, Chinese international students and skilled workers in the UK have motivated Chinese entrepreneurs to develop their businesses in the well-regulated British business environment, with the intention to standardise their enterprises in the UK business environment, albeit to achieve greater growth in Chinese mainstream markets. They felt that the 'British mainstream markets were places for their businesses to learn relevant international standards and business formalities' while 'Chinese mainstream markets had the real potential to achieve substantial growth for their enterprises'. Third, with respect to education, the entrepreneurs interviewed were all highly educated, and the education they received had a profound impact on their breakout locations and future breakout spaces. In particular, all of the graduate entrepreneurs felt that they would not want to follow the same path as their predecessor Chinese migrant entrepreneurs entering the Chinese catering industry when they first started their businesses. They considered their business adventures as an essential means to express their life values. Lastly, in terms of class, most student entrepreneurs are considered middleclass entrepreneurs, with most of them choosing to breakout into either the host-country or homecountry mainstream markets, while elite entrepreneurs considered breaking into both the hostcountry and home-country mainstream markets. Arguably due to their social class, all the elite and graduate entrepreneurs decided not to start their businesses in the traditional catering industry.

Through the lens of Multicultural Hybridism and from the perspective of the entrepreneurs, breakout is understood as the entrepreneurial transformation process of a hybrid fusion on both the entrepreneur as a multicultural mix and the superdiverse transnational context as a complex mix of structural and social embeddedness. Through dynamic interactions between Opportunity Structure in the superdiverse business contexts and the Opportunity Recognition of translational migrant 
entrepreneurs, the transformational process of breakout creates hybrid multicultural economic, social and cultural spaces. In particular, the conceptual framework of Multicultural Hybridism incorporates home-country mainstream markets parallel to host-country mainstream markets, avoiding the singular conceptualisation of the host-country mainstream market as the only breakout destination for ethnic entrepreneurs. Examination of these interviews with first-generation Chinese entrepreneurs highlights that a great proportion of transnational entrepreneurs in the advanced manufacturing, service and creative industries aspire to not only grow businesses in the host-country British mainstream markets, but also to explore opportunities in the home-country Chinese mainstream economies. The significance of the home-country Chinese market as an alternative breakout destination lies in its bidirectional transnational perspective, which expands the concept of breakout into a new sphere of 'break-beyond'. There are also a small number of mainly female entrepreneurs who intend to break back from British mainstream markets into Chinese ethnic markets in the UK, motivated by a perceived stability and sense of community. The desire shown by these Chinese entrepreneurs to explore business opportunities in their home-country Chinese mainstream markets as well as breaking back into Chinese niche markets in Birmingham coincides with an unwillingness, demonstrated by most Chinese transnational enclaved entrepreneurs, to enter mainstream British markets. The unwillingness is not due to insufficient entrepreneurial resources or structural obstacles, but on account of the relatively favourable environment in Chinese ethnic markets, with more competitive economic rewards as well as cultural and social benefits within the co-ethnic social network. To some extent, it also provides explanations for the unexpected low breakout rates of Chinese entrepreneurs into mainstream British markets. Therefore, this study has contributed to the theory of migrant entrepreneurship through the construction of Multicultural Hybridism, to reconceptualise breakout as a hybrid transformation process through inter-ethnic opportunity recognition. In particular, the reconceptualisation of breakout incorporates the homecountry mainstream market as an alternative breakout destination, to stress the plurality in future spaces of migrant entrepreneurship. This provides insights into the future road ahead for transnational migrant entrepreneurship, with a vision of gaining economic growth and achieving social integration in a superdiverse multicultural context.

\section{Appendix}

Table 1. Interviews with First-Generation Mainland Chinese Entrepreneurs in Birmingham

\begin{tabular}{|c|c|c|c|c|c|}
\hline Name & Type of Business & Age & Gender & Education Background & Migration History \\
\hline L & Restaurant & $40 \mathrm{~s}$ & Male & Bachelor's Degree & Skilled Worker \\
\hline S & Restaurant & $40 \mathrm{~s}$ & Male & Bachelor's Degree & Skilled Worker \\
\hline J & Education Service & $50 \mathrm{~s}$ & Female & Master's Degree & $\begin{array}{c}\text { International } \\
\text { Student }\end{array}$ \\
\hline $\mathrm{A}$ & $\begin{array}{c}\text { Business } \\
\text { Consultancy }\end{array}$ & $30 \mathrm{~s}$ & Female & Master's Degree & $\begin{array}{c}\text { International } \\
\text { Student }\end{array}$ \\
\hline $\mathrm{M}$ & $\begin{array}{c}\text { Education Service } \\
\text { T }\end{array}$ & $30 \mathrm{~s}$ & Female & Master's Degree & $\begin{array}{c}\text { International } \\
\text { Student }\end{array}$ \\
\hline $\mathrm{N}$ & $\begin{array}{c}\text { Broadcast } \\
\text { Entertainment } \\
\text { Service }\end{array}$ & $40 \mathrm{~s}$ & Female & Bachelor's Degree & Skilled Worker \\
\hline $\mathrm{F}$ & $\begin{array}{c}\text { Education } \\
\text { Consultant Service } \\
\text { Accountancy } \\
\text { Service }\end{array}$ & $30 \mathrm{~s}$ & Male & Machelor's Degree & $\begin{array}{c}\text { International } \\
\text { Student }\end{array}$ \\
\hline $\mathrm{W}$ & $40 \mathrm{~s}$ & Male & Master's Degree & $\begin{array}{c}\text { International } \\
\text { Student }\end{array}$ \\
\hline
\end{tabular}


Multicultural Hybridism as a Dynamic Framework to Reconceptualise Breakout in a Superdiverse and Transnational Context

\begin{tabular}{|c|c|c|c|c|c|}
\hline $\mathrm{D}$ & $\begin{array}{c}\text { Designer } \\
\text { Watchmaker }\end{array}$ & $30 \mathrm{~s}$ & Male & Master's Degree & $\begin{array}{c}\text { International } \\
\text { Student }\end{array}$ \\
\hline $\mathrm{C}$ & $\begin{array}{c}\text { Digital Marketing } \\
\text { Agency }\end{array}$ & $40 \mathrm{~s}$ & Male & Master's Degree & $\begin{array}{c}\text { International } \\
\text { Student }\end{array}$ \\
\hline $\mathrm{I}$ & $\begin{array}{c}\text { Designer Products } \\
\text { Online Shop }\end{array}$ & $40 \mathrm{~s}$ & Female & Master's Degree & $\begin{array}{c}\text { International } \\
\text { Student }\end{array}$ \\
\hline $\mathrm{E}$ & $\begin{array}{c}\text { Vehicle Sales and } \\
\text { Rental Dealership }\end{array}$ & $30 \mathrm{~s}$ & Male & Master's Degree & $\begin{array}{c}\text { International } \\
\text { Student }\end{array}$ \\
\hline $\mathrm{X}$ & $\begin{array}{c}\text { Medical Equipment } \\
\text { Inventor and } \\
\text { Manufacturer }\end{array}$ & $40 \mathrm{~s}$ & Male & Doctoral Degree & $\begin{array}{c}\text { International } \\
\text { Student }\end{array}$ \\
\hline $\mathrm{Y}$ & $\begin{array}{c}\text { Electronic } \\
\text { Appliance } \\
\text { Manufacturer }\end{array}$ & $50 \mathrm{~s}$ & Male & Doctoral Degree & $\begin{array}{c}\text { International } \\
\text { Student }\end{array}$ \\
\hline $\mathrm{R}$ & $\begin{array}{c}\text { Computer } \\
\text { Consumable } \\
\text { Manufacturer }\end{array}$ & $40 \mathrm{~s}$ & Female & Doctoral Degree & $\begin{array}{c}\text { International } \\
\text { Student }\end{array}$ \\
\hline
\end{tabular}

\section{References}

Arenius, P. and Clercq, D.D. (2005). A network-based approach on opportunity recognition, Small Business Economics, 24, 249-265.

Aldrich, H. and Waldinger, R. (1990). Ethnicity and entrepreneurship. Annual Review of Sociology, 16(1), 111-135.

Allen, R. and Busse, E. (2016). The social side of ethnic entrepreneur breakout: Evidence from Latino immigrant business owners. Ethnic and Racial Studies, 39(4), 653-670.

Appiah, K. (1993). Thick translation. Callaloo, 16(4), 808-819.

Arrighetti, A., Daniela Bolzani, D. and Lasagni, A. (2014). Beyond the enclave? Break-outs into mainstream markets and multicultural hybridism in ethnic firms. Entrepreneurship and Regional Development, 26(9-10), 753-777.

Backhaus, J. (2002). The seventh chapter of Schumpeter's the theory of economic development presentation. Industry and Innovation, 9(1-2), 91-92.

Bagwell, S. (2018). From mixed embeddedness to transnational mixed embeddedness: An exploration of Vietnamese businesses in London. International Journal of Entrepreneurial Behavior and Research, 24(1), 104-120.

Barberis, E. and Solano, G. (2018). Mixed embeddedness and migrant entrepreneurship: Hints on past and future directions. An introduction. Sociologica, 12(2), 1-22.

Barrett, G. A., Jones, T. P., and McEvoy, D. (1996). Ethnic minority business: Theoretical discourse in Britain and North America. Urban Studies, 33(4-5), 783-809.

Barrett, R. and Vershinina, N. (2017). Intersectionality of ethnic and entrepreneurial identities: A study of post-war Polish entrepreneurs in an English city. Journal of Small Business Management, 55(3), 430-443.

Basch, L., Glick-Schiller, N. and S. Blanc-Szanton (Eds.). (1994). Nations unbound: Transnational projects, postcolonial predicaments, and deterritorialized nation-states. Basel: Gordon and Breach. Baycan-Levent, T. and Nijkamp, P. (2009). Characteristics of migrant entrepreneurship in Europe. Entrepreneurship and Regional Development, 21(4), 375-397.

Beiser, M. and Hou, F. (2000). Gender differences in language acquisition and employment consequences among Southeast Asian refugees in Canada. Canadian Public Policy / Analyse De Politiques, 26(3), 311-330. 
Chan, S. (1997). Migration, cultural identity and assimilation effects on entrepreneurship for the Overseas Chinese in Britain. Asia Pacific Business Review, 3(4), 211-222.

Chen, W., Tan, J., and Tu, F. (2015). Minding the gender gap: Social network and Internet correlates of business performance among Chinese immigrant entrepreneurs. American Behavioral Scientist, 59(8), 977-991.

Daniel, E., Henley, A. and Anwar, M.N. (2019). Contemporary ethnic minority entrepreneurship in the UK: A quantitative exploration of break out and entrepreneurial quality. International Journal of Entrepreneurial Behavior and Research, 25(7), 1410-1432.

Farr-Wharton, R. and Brunetto, Y. (2007). Women entrepreneurs, opportunity recognition and government-sponsored business networks: A social capital perspective. Women in Management Review, 22(3), 187-207.

Glaser, B. (1998). Doing grounded theory. California: Sociology Press.

Goldkuhl, G. and Cronholm, S. (2010). Adding theoretical grounding to grounded theory:

Toward multi-grounded theory. International Journal of Qualitative Methods, 9 (2) 187-205. González, J. and Campbell, D. (2018). Beyond the enclave: Success strategies of immigrant entrepreneurs, International Journal of Applied Management and Technology, 17(1), 46-57. Greve, A. and Salaff, J. (2005). Social network approach to understand the ethnic economy: A theoretical discourse. Geo Journal, 64, 7-16.

Henry, N., McEwan, C. and Pollard, J. (2002). Globalization from below: Birmingham postcolonial workshop of the world. Area, 34, 117-127.

Hutchison, A., Johnston, L. and Breckon, J. (2009). Using QSR-NVivo to facilitate the development of a grounded theory project: An account of a worked example. International Journal of Social Research Methodology, 13(4), 283-302.

Jones, T., Ram, M., Edwards, P., Kiselinchev, A., and Muchenje, L. (2012). New migrant enterprise: Novelty or historical continuity? Urban Studies, 49(14), 3159-3176.

Jones,T., Ram, M., Edwards, P., Kiselinchev, A. and Muchenje, L. (2014). Mixed embeddedness and new migrant enterprise in the UK. Entrepreneurship and Regional Development, 26(5-6), 500-520 .

Jones, T., Ram, M., Li, Y., Edwards, P. and Villares, M. (2015). Super-diverse Britain and new migrant enterprises. IRiS Working Paper Series, No. 8/2015. Birmingham: Institute for Research into Superdiversity.

Kloosterman, R., Leun, J. and Rath, J. (1999). Mixed embeddedness: (In)formal economic activities and immigrant businesses in the Netherlands. International Journal of Urban and Regional Research, 23(2), 253-267.

Kloosterman, R., and Lambregts, B. (2001). Clustering of economic activities in polycentric urban regions: The case of the Randstad. Urban Studies, 38(4), 717-732.

Kloosterman, R. and Rath, J. (2001). Immigrant entrepreneurs in advanced economies: Mixed embeddedness further explored. Journal of Ethnic and Migration Studies, 27(2), 189-201.

Kloosterman, R. (2006). Mixed embeddedness as a conceptual framework for exploring immigrant entrepreneurship. Eurex Lecture 8. Amsterdam institute of Metropolitan and International Development Studies.

Kloosterman, R. (2010). Matching opportunities with resources: A framework for analysing migrant entrepreneurship from a mixed embeddedness perspective. Journal of Entrepreneurship and Regional Development, 22(1),.25--45.

Kloosterman, R., Rusinovic, K. and Yeboah, D. (2016). Super-diverse migrants-similar trajectories? Ghanaian entrepreneurship in the Netherlands seen from a Mixed Embeddedness perspective. Journal of Ethnic and Migration Studies, 42(6), 913-932.

Kloosterman, R. and Rath, J. (2018). Mixed Embeddedness revisited: A conclusion to the symposium. Sociologica, 12(2), 103-114. 
Lassalle, P. and Scott, J. (2015)."Breaking out": Exploring the diversification process among ethnic minority entrepreneurs. 38th Annual Institute for Small Business and Entrepreneurship Conference 2015, 11-12 November 2015, Glasgow.

Lassalle, P. and McElwee, G. (2016). Polish entrepreneurs in Glasgow and entrepreneurial opportunity structure. International Journal of Entrepreneurial Behavior and Research, 22(2), 260 281.

Lassalle, P. (2018). Opportunity recognition among migrant entrepreneurs: Household, community and the haphazard nature of migrants' entrepreneurial decisions. The International Journal of Entrepreneurship and Innovation, 19(3), 143-154.

Lassalle, P. and Scott, J. (2018). Breaking-out? A reconceptualisation of the business development process through diversification: the case of Polish new migrant entrepreneurs in Glasgow, Journal of Ethnic and Migration Studies, 44(15), 2524-2543.

Light, H. and Rosenstein, N. (1995). Race, ethnicity, and entrepreneurship in urban America. New York: Aldine de Gruyter.

Ma, R., Huang, Y.-C. and Shenkar, O. (2011). Social networks and opportunity recognition: A cultural comparison between Taiwan and the United States. Strategic Management, 32(11), 11831205.

Mason, M. (2010). Sample size and saturation in PhD Studies using qualitative interviews.

Forum: Qualitative Social Research, 11(3). Retrieved from http://www.qualitativeresearch.net/index.php/fqs/article/view/1428.

McEvoy, D. and Hafeez, K. (2007). Ethnic enclaves or middleman minority? Regional patterns of ethnic minority entrepreneurship in Britain. Working Paper 07-24. Retrieved from https://www.researchgate.net/profile/David_Mcevoy3/publication/247835723_Ethnic_enclav es_or_middleman_minority_Regional_patterns_of_ethnic_minority_entrepreneurship_in_Bri tain/links/0a85e538744eea198c000000.pdf

Morse, J. M. (2001). Using shadowed data. Qualitative Health Research, 11, 291-292.

McEwan, C., Pollard, J. and Henry, N. (2005). The 'global' in the city economy: Multicultural economic development in Birmingham. International Journal of Urban and Regional Research, 29(4), 916-933.

Narayan, K. (1993). How native is a "native" anthropologist? American Anthropologist, 95(3), 671-686.

Parker, D. (1998). Chinese people in Britain: Histories, futures and identities. In G. Benton (Ed.), The Chinese in Europe (pp. 67-95). London: Palgrave Macmillan,

Portes, A. and Yiu, J. (2013). Entrepreneurship, transnationalism, and development. Migration Studies, 1(1), 75-95.

Ram, M. and Hillin, G. (1994). Achieving 'break-out': Developing mainstream ethnic minority businesses. Journal of Small Business and Enterprise Development, 1(2), 15-21.

Ram, M., Smallbone, D., Deakins, D. and Jones, T. (2003). Banking on 'break-out': Finance and the development of ethnic minority businesses. Journal of Ethnic and Migration Studies, 29(4), 663-681.

Ram, M. and Jones, T. (2008). Ethnic-minority businesses in the UK: A review of research and policy developments. Environment and Planning C: Government and Policy, 26(2), 352-374. Ram, M., Jones, T., Edwards, P., Kiselinchev, A., Muchenje, L., and Woldesenbet, K. (2013). Engaging with super-diversity: New migrant businesses and the research-policy nexus. International Small Business Journal, 31(4), 337-356.

Rodgers, P. and Williams C.C. (2019). Entrepreneurial practices in an age of super-diversity: A study of Ukrainian entrepreneurs in the UK. In V. Ramadani (Ed.), Informal ethnic entrepreneurship (pp. 29-44). Cham: Springer.

Sassen, S. (1988). The mobility of labor and capital: Studies in international investment and labor flow. New York: Cambridge University Press. 
Sepulveda, L., Syrett, S. and Lyon, F. (2011). Population super-diversity and new migrant enterprise: The case of London. Entrepreneurship and Regional Development, 23(7/8), 469-497. Simpson, L. (2007). Population forecasts for Birmingham, CCSR Working Paper 2007-12, Cathie Marsh Centre for Census and Survey Research, Manchester University. Available from http://hummedia.manchester.ac.uk/institutes/cmist/archive-publications/workingpapers/2007/2007-12-population-forecasts-for-birmingham.pdf.

Solano, G. (2016). Multifocal entrepreneurial practices: The case of Moroccan import/export businesses in Milan. International Journal of Entrepreneurship and Small Business, 29(2), 176198.

Starks, H. and Trinidad, S.B. (2007). Choose your method: A comparison of phenomenology, discourse analysis, and grounded theory. Qualitative Health Research, 17(10), 1372-80.

Stauth, G. (1992). Nietzsche, Weber, and the affirmative sociology of culture. European Journal of Sociology, 33(2), 219-247.

Strauss, A. and Corbin, J. (1990). Basics of qualitative research - techniques and procedures for developing grounded theory. California: Sage.

Urquhart C. and Fernández W. (2016). Using grounded theory method in information systems: The researcher as blank slate and other myths. In L.P Willcocks (Ed.), Enacting research methods in information systems (pp. 129-156). Cham: Palgrave Macmillan.

Valenzuela-Garcia, H., Güell, B., Parella, S., Molina, J. and Miranda Jessica Lubbers, M. (2018). Placing migrant entrepreneurship: Migrant economy debates through new spatial lenses.

Sociologica, 12(2), 39-56.

Vershinina, N. and Rodgers, P. (2019). Migration, enterprise and society. International Journal of Entrepreneurial Behavior and Research, 25(5), 774-779.

Vertovec, S. (1999). Conceiving and researching transnationalism. Ethnic and Racial Studies, 22(2), 447-462,

Vertovec, S. (2007). Super-diversity and its implications. Ethnic and Racial Studies, 30(6), 10241054.

Vertovec, S. (2009). Transnationalism. London and New York: Routledge.

Wahlbeck, Ö. (2018). Combining mixed embeddedness and transnationalism: The utilization of social resources among Turkish migrant entrepreneurs. Sociologica, 12(2), 73-86.

Waldinger, R., Aldrich, R., and Ward, R. (1990). Opportunities, group characteristics, and strategies. In R. Waldinger (Ed.), Ethnic entrepreneurs. Immigrant business in industrial societies (pp. 13-48). Newbury Park, CA: Sage.

Waldinger, R. (1993). The ethnic enclave debate revisited. International Journal of Urban Regional Research, 17, 44-4-452.

Waldinger, R. and Fitzgerald, D. (2004). Transnationalism in question. American Journal of Sociology, 109(5), 1177-1195.

Wang, Q. (2013). Constructing a multilevel spatial approach in ethnic entrepreneurship studies. International Journal of Entrepreneurial Behavior and Research, 19(1), 97-113. Ward, R. (1985). Minority settlement and the local economy, in: Roberts, B., Finnegan, R. and Gallie , D. (Eds.) New Approaches to Economic Life (pp. 198-211). Manchester: Manchester University Press.

Ward, R. (1986). Ethnic business and economic change: an overview. International Small Business Journal, 4(3), 10-12.

Welter, F. (2011). Contextualizing entrepreneurship - Conceptual challenges and ways forward. Entrepreneurship Theory and Practice, 35(1), 165-184.

Werbner, P. (1990). Renewing an industrial past: British Pakistani entrepreneurship in Manchester. Migration, 8, 17-41.

Wilson, K. and Portes, A. (1980). Immigrant enclaves: An analysis of the labour market experiences of Cubans in Miami. American Journal of Sociology, 88, 295-319. 
Wu, B. and Liu, H. (2014). Bringing class back in: Class consciousness and solidarity among Chinese migrant workers in Italy and the UK. Ethnic and Racial Studies, 37(8), 1391-1408. Yamamura, S. and Lassalle, P. (2020). Proximities and the emergence of regional industry: evidence of the liability of smallness in Malta. European Planning Studies, 28(2), 380-399. Zhang, D. (2012). Co-ethnic network, social class, and heritage language maintenance among Chinese immigrant families. Journal of Language, Identity and Education, 11(3), 200-223. Zhang, X., Ma, X., Wang, Y., Li, X., and Huo, D. (2016). What drives the internationalization of Chinese SMEs? The joint effects of international entrepreneurship characteristics, network ties, and firm ownership. International Business Review, 25, 522-534.

Zubair, M. and Brzozowski, J. (2018). Entrepreneurs from recent migrant communities and their business sustainability. Sociologica, 12(2), 57-72. 
Multicultural Hybridism as a Dynamic Framework

to Reconceptualise Breakout in a Superdiverse and Transnational Context

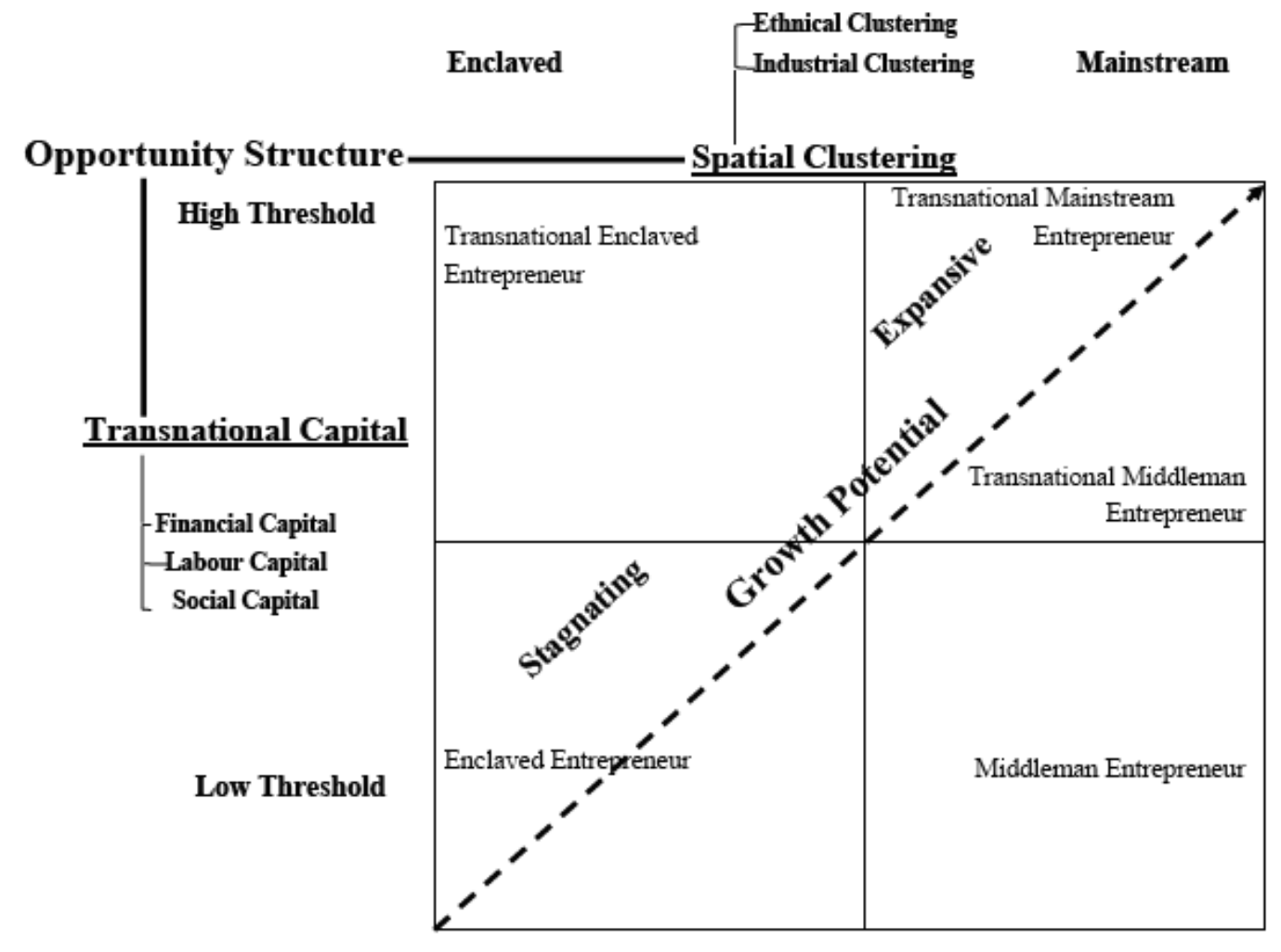

Figure 1. Opportunity Structure: A Typology of Transnational Migrant Entrepreneurs adapted from Kloosterman (2006) and Lassalle and Scott (2015)

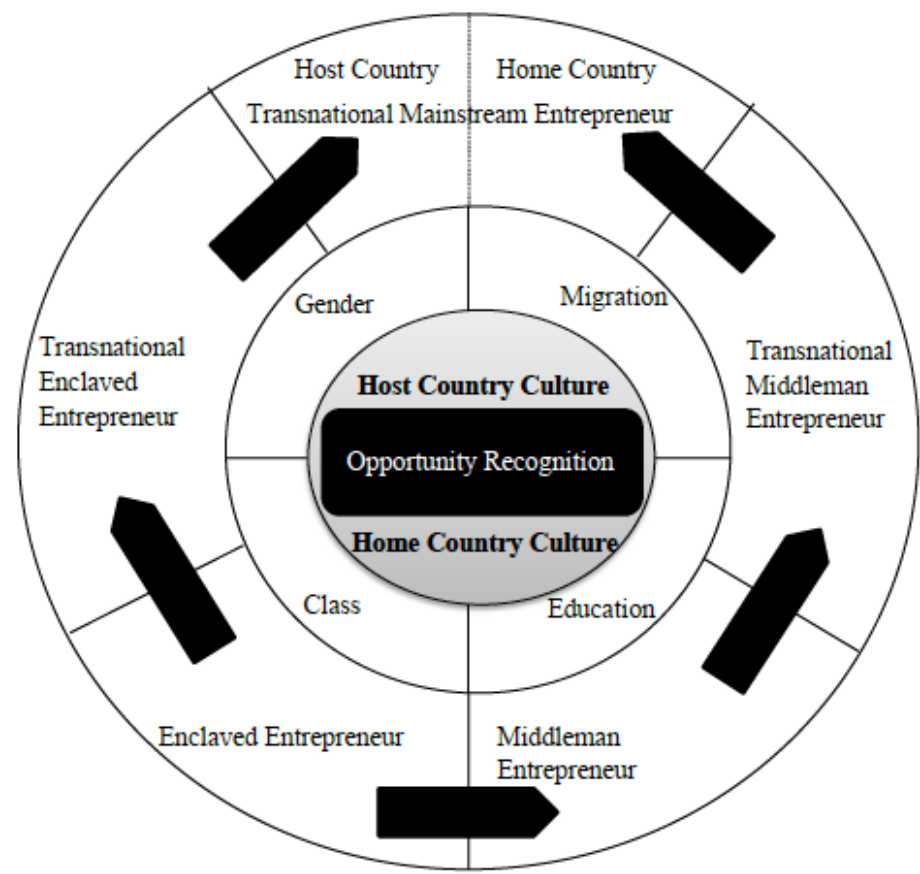

Figure 2. Opportunity Recognition:

A Framework for the Breakout Process in Superdiverse Contexts adapted from Lassalle and Scott (2015) and Arrighetti, Bolzani, and Lasagni (2014) 
Multicultural Hybridism as a Dynamic Framework

to Reconceptualise Breakout in a Superdiverse and Transnational Context

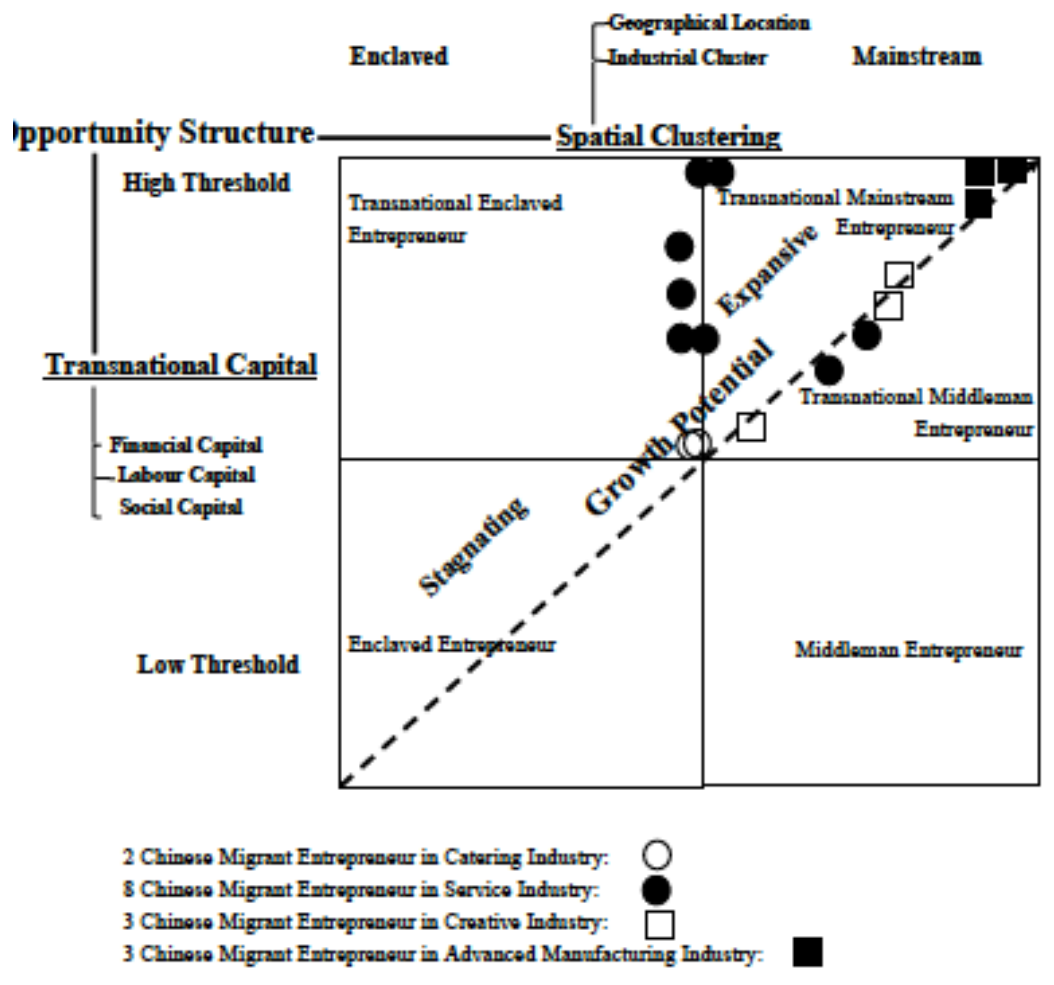

Figure 3. Transnational Opportunity Structure on the Basis of a Typology of Transnational Migrant Entrepreneurs

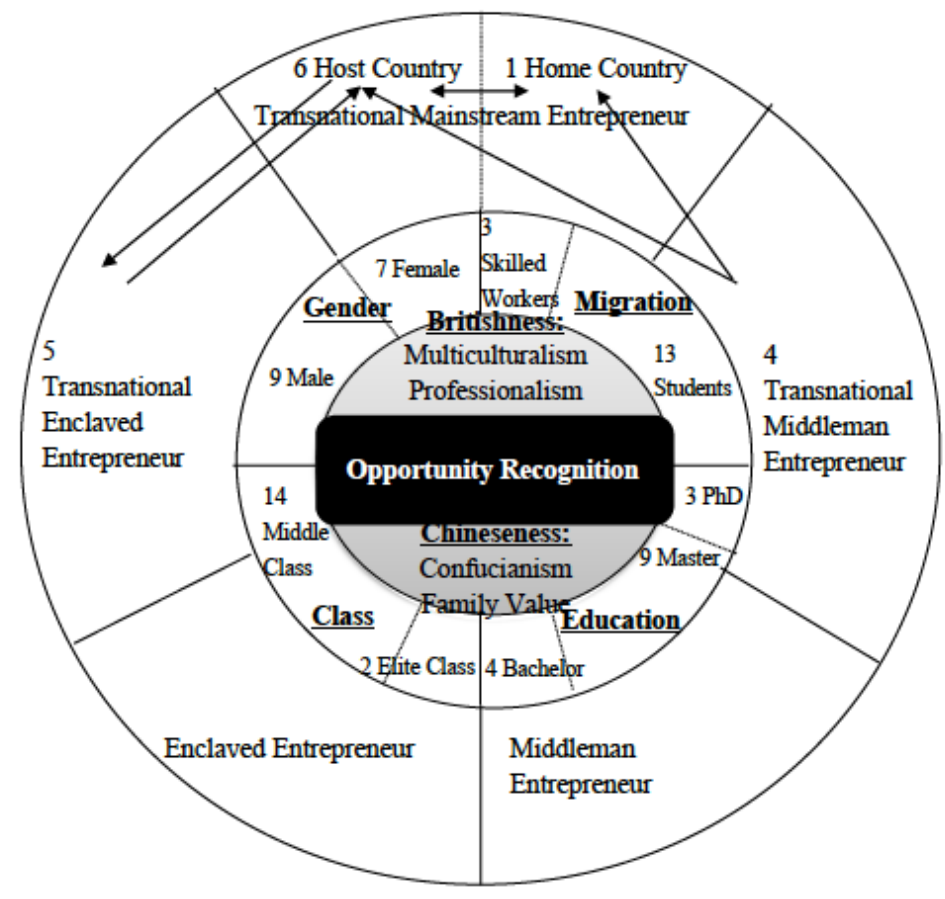

Figure 4. Superdiversity of Opportunity Recognition on the Basis of A Framework for the Breakout Process in Superdiverse Contexts 